\title{
EFFECT OF VITAMIN B12 ON THE INTERMEDIARY METABOLISM OF CHICKS $^{1}$
}

\author{
YOSHIKAZU SAHASHI, KIICHI IWAMOTO AND JUNZO HAYASHI \\ Laboratory of Biochemistry, Tokyo Univesity of Agriculture, Setagaya, \\ Tokyo and Shiga Agricultural College, Ritto-cho, Shiga-ken.
}

(Received July 21, 1955)

In 1953, the authors (1) reported that a decrease of thiamine and vitamin $B_{12}$ was found in the blood as the result of the energy metabolism of cattle, and that the deficiency of the vitamins was completely protected against by a prophylactic injection of the vitamins at the beginning of the experiment. The intimate relation between both vitamins and metabolism was thus recognized for the formation of enzymic system containing thiamine in animal bodies. Vitamin $\mathrm{B}_{12}$ nutrition has since been reported on for a number of different organisms as well as the effects of the vitamin upon the low requirement of various nutrients, but few reports have appeared with reference to the enzyme-forming activity of vitamin $B_{12}$. The authors have attempted to study the effects of vitamin $\mathrm{B}_{12}$ on the formation of enzymes containing thiamine, nicotinic acid and pantothenic acid, and it was confirmed that vitamin $\mathrm{B}_{12}$ may be closely related to the energy metabolism of the above-mentioned vitamins. (2)

\section{EXPERIMENTAL AND RESULTS}

\section{Preparation of Vitamin $B_{12}$-deficient Chicks (3).}

Fifty-day-old chicks were previously fed on a vitamin $\mathrm{B}_{12}$-deficient diet composed of a mixture of corn meal 37, wheat flour 10, wheat bran 10 , rice bran 10 , soy bean meal 27 , soy bean oil (supplemented with cod-liver oil in the proportion of $14: 1) 3$, and mineral matter $\left(\mathrm{NaCl}, \mathrm{CaCO}_{3}\right.$ and bone dust) 3 . Chicks were divided into two groups: the 1 st group of 5 chicks weighing aver. $265 \mathrm{~g}$ each were orally administered with $1 \gamma$ of vitamin $B_{12}$, while the 2 nd group of 5 chicks served as a control. After 20 days, vitamin $B_{12}$ in the blood was determined by Euglena method, and the change in the vitamin content of the liver and blood was studied (4). The results are shown in Tables I-II. There was a distinct difference in the vitamin $\mathrm{B}_{12}$ content of the liver, but scarcely any difference, in the vitamin content of the blood was observed in the period of 20 days.

\footnotetext{
${ }^{1}$ Biochemical Studies on Vitamin B1.2. VIII.
} 
Table I

The Change in Body Weight of Chicks with Vitamin B12-Deficiency.

\begin{tabular}{r|c|c|cc|cc}
\hline \hline \multirow{2}{*}{ Days } & $\begin{array}{c}\text { Amount } \\
\text { of } \\
\text { ration }\end{array}$ & $\begin{array}{c}\text { Amount } \\
\text { of green } \\
\text { leaves }\end{array}$ & \multicolumn{2}{|c|}{$\begin{array}{l}\text { Body wt. of the } \\
\text { group treated with } \\
\text { vitamin Br2 }\end{array}$} & \multicolumn{2}{|c}{ Body wt. of the } \\
control group
\end{tabular}

Table II

The Change in Vitamin $B_{12}$ in the Liver and Blood of Vitamin B12-Deficient Chicks.

\begin{tabular}{|c|c|c|c|}
\hline Organ & $\begin{array}{l}\text { No. of } \\
\text { animals }\end{array}$ & $\begin{array}{l}\text { Vitamin } B_{12} \text { content } \\
\text { of the group treated } \\
\text { with vitamin } B_{12}\end{array}$ & $\begin{array}{l}\text { Vitamin } B_{1.2} \text { content } \\
\text { in the control group }\end{array}$ \\
\hline \multirow{8}{*}{ Liver } & & $m \boldsymbol{r} / g$ & $m \gamma / g$ \\
\hline & 1 & 29.65 & 16.80 \\
\hline & 2 & 29.80 & 13.20 \\
\hline & 3 & 29.80 & 7.95 \\
\hline & 4 & 19.80 & 13.20 \\
\hline & 5 & 32.00 & 12.20 \\
\hline & 6 & 29.10 & - \\
\hline & Aver. & & 12.03 \\
\hline \multirow{2}{*}{ Blood $^{a}$} & & $m \gamma / m l$ & $m \gamma / m l$ \\
\hline & & 2.75 & 2.58 \\
\hline
\end{tabular}

$a$ The collected blood of 6 chicks was investigated because the blood of each chick was insufficient.

\section{Metabolic State of Pantothenic Acid and Nicotinic Acid in Vitamin}

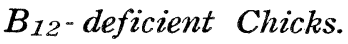

Further experiments were carried out with vitamin $\mathrm{B}_{12}$-deficient chicks obtained as mentioned above. The change in pantothenic acid was tested by the microbiological assay of Snell using Lactobacillus arabinosus 17-5. The results are given in Table III. 
Table III

The Change in Pantothenic Acid in the Liver and Blood.

\begin{tabular}{|c|c|c|c|c|c|c|c|c|c|}
\hline \multirow[b]{2}{*}{ Organ } & \multirow{2}{*}{$\begin{array}{l}\text { No. of } \\
\text { animals }\end{array}$} & \multicolumn{4}{|c|}{$\begin{array}{l}\text { Pantothenic acid in the group } \\
\text { treated with vitamin } B_{12}\end{array}$} & \multicolumn{4}{|c|}{$\begin{array}{l}\text { Pantothenic acid in the } \\
\text { control group }\end{array}$} \\
\hline & & Total & Free & Conj. & nj. & Total & Free & Conj. & Conj. $/$ Total \\
\hline \multirow[b]{2}{*}{ Liver } & & $\gamma / g$ & $\gamma / g$ & $\gamma / g$ & $\%$ & $\gamma / g$ & $\gamma / g$ & $\gamma / g$ & $\%$ \\
\hline & $\begin{array}{c}1 \\
2 \\
3 \\
4 \\
5 \\
\text { Aver. }\end{array}$ & $\begin{array}{l}35.0 \\
38.0 \\
35.0 \\
34.0 \\
29.0 \\
34.2\end{array}$ & $\begin{array}{l}4.0 \\
4.0 \\
3.0 \\
3.5 \\
3.2 \\
3.5\end{array}$ & $\begin{array}{l}31.0 \\
34.0 \\
32.0 \\
30.5 \\
25.8 \\
30.6\end{array}$ & $\begin{array}{l}88.6 \\
89.5 \\
91.4 \\
89.5 \\
89.0 \\
89.6\end{array}$ & $\begin{array}{l}28.0 \\
42.0 \\
36.0 \\
40.5 \\
42.5 \\
37.8\end{array}$ & $\begin{array}{l}4.0 \\
6.0 \\
6.5 \\
5.2 \\
5.0 \\
5.3\end{array}$ & $\begin{array}{l}24.0 \\
36.0 \\
29.5 \\
35.3 \\
37.5 \\
32.4\end{array}$ & $\begin{array}{l}85.7 \\
85.7 \\
81.9 \\
87.2 \\
88.2 \\
85.9\end{array}$ \\
\hline \multirow{2}{*}{ Blood $^{a}$} & & $\gamma / m l$ & $\gamma / m l$ & $\gamma / m l$ & $\%$ & $\gamma / m l$ & $\gamma / m l$ & $r / m l$ & $\%$ \\
\hline & & 0.75 & 0.62 & 0.13 & 17.3 & 0.66 & 0.57 & 0.09 & 13.6 \\
\hline
\end{tabular}

$a$ The collected blood of 5 chicks was investigated.

Similar experiments were also performed to study the change in nicotinic acid in the vitamin $B_{12}$-deficient chicks. Nicotinic acid was determined microbiologically by Snell method using Lactobacillus arabinosus (Table IV).

Table IV

The Change in Nicotinic Acid in the Liver and Blood

\begin{tabular}{|c|c|c|c|c|c|c|c|c|c|}
\hline \multirow[b]{2}{*}{ Organ } & \multirow{2}{*}{$\begin{array}{l}\text { No. of } \\
\text { animals }\end{array}$} & \multicolumn{4}{|c|}{$\begin{array}{l}\text { Nicotinic acid in the group } \\
\text { treated with vitamin } \mathrm{B}_{12}\end{array}$} & \multicolumn{4}{|c|}{$\begin{array}{l}\text { Nicotinic acid in the } \\
\text { control group }\end{array}$} \\
\hline & & Total & Free & Conj. & Conj. $/$ Total & Total & Free & Conj. & Conj. $/$ Total \\
\hline \multirow[b]{2}{*}{ Liver } & \multirow[b]{2}{*}{$\begin{array}{c}1 \\
2 \\
3 \\
4 \\
5 \\
\text { Aver. }\end{array}$} & $m g / 100 g$ & $\mathrm{mg} / 100 \mathrm{~s}$ & $m g / 100 g$ & $\%$ & $m g / 100 g$ & $m g / 100 g$ & $m g / 100 g$ & $\%$ \\
\hline & & $\begin{array}{l}20.13 \\
17.72 \\
21.78 \\
17.55 \\
19.27\end{array}$ & $\begin{array}{l}6.50 \\
5.18 \\
7.89 \\
6.22 \\
6.44\end{array}$ & $\begin{array}{l}13.63 \\
12.54 \\
13.89 \\
11.33 \\
12.85\end{array}$ & $\begin{array}{l}67.7 \\
70.8 \\
63.8 \\
64.6 \\
66.6\end{array}$ & $\begin{array}{l}21.00 \\
26.70 \\
16.20 \\
19.58 \\
18.30 \\
20.36\end{array}$ & $\begin{array}{r}8.70 \\
14.55 \\
6.90 \\
7.88 \\
5.83 \\
8.78\end{array}$ & $\begin{array}{r}12.30 \\
12.15 \\
9.30 \\
11.70 \\
12.47 \\
11.58\end{array}$ & $\begin{array}{l}58.6 \\
45.5 \\
57.4 \\
59.7 \\
66.5 \\
56.9\end{array}$ \\
\hline Blood $^{\alpha}$ & & $\begin{array}{c}m g / m l \\
1.54\end{array}$ & $\begin{array}{c}m g / m l \\
0.17\end{array}$ & $\begin{array}{c}m g / m l \\
1.37\end{array}$ & $\begin{array}{l}\% \\
88.0\end{array}$ & $\begin{array}{c}m g / m l \\
1.29\end{array}$ & $\begin{array}{c}m g / m l \\
0.30\end{array}$ & $\begin{array}{c}m g / m l \\
0.99\end{array}$ & $\begin{array}{c}\% \\
77.0\end{array}$ \\
\hline
\end{tabular}

a The same as described in Table II.

From the above findings, it seems to be probable that some relation of vitamin $B_{1} 2$ to pantothenic acid and nicotinic acid may exist for the in vivo formation of the conjugated forms of these vitamins.

3. Further Experiments with 15-Day-Old Chicks.

Fifty young chicks were previously fed on a vitamin B12-deficient ration composed of "Awa" (Foxtail millet) 5, corn meal 22, wheat flour 10, wheat bran 10 , rice bran 10 , soy bean meal 30 , polished rice 7 , soy bean oil (supplemented with cod-liver oil in the proportion of $15: 1$ ) 3 , and 
mineral matter $\left(\mathrm{NaCl}, \mathrm{CaCO}_{3}\right.$ and bone dust) 3. After 15 days, the chicks were divided into two groups. The 1st group consisting of 25 chicks weighing aver. $78.7 \mathrm{~g}$ each were administered with $1 \gamma$ of vitamin $\mathrm{B}_{12}$ per day per os, while the 2nd group of 25 chicks served as a control. After 45 days of treatment with vitamin $\mathrm{B}_{12}$, the change in the metabolic state of pantothenic acid and nicotinic acid was again tested microbiologically as mentioned above. Results shown in Table $\mathrm{V}-\mathrm{X}$ indicated a more satisfactory response than in the 1st experiment.

Table $V$

The Change in Body Weight of Vitamin B12Deficient Chicks during the Experiment.

The figures indicate the average body weight of 7 chicks.

\begin{tabular}{r|c|c}
\hline \multirow{2}{*}{ Days } & $\begin{array}{c}\text { Group treated with } \\
\text { vitamin } \text { B } 12\end{array}$ & Control group \\
\hline 0 & $g$ & $g$ \\
10 & 78.7 & 83.1 \\
20 & 127.1 & 122.3 \\
30 & 190.9 & 176.5 \\
40 & 339.3 & 305.4 \\
45 & 424.3 & 370.7 \\
& 528.6 & 432.0 \\
\hline
\end{tabular}

Table VI

The Change in Liver Weight of Vitamin B12-Deficient Chicks

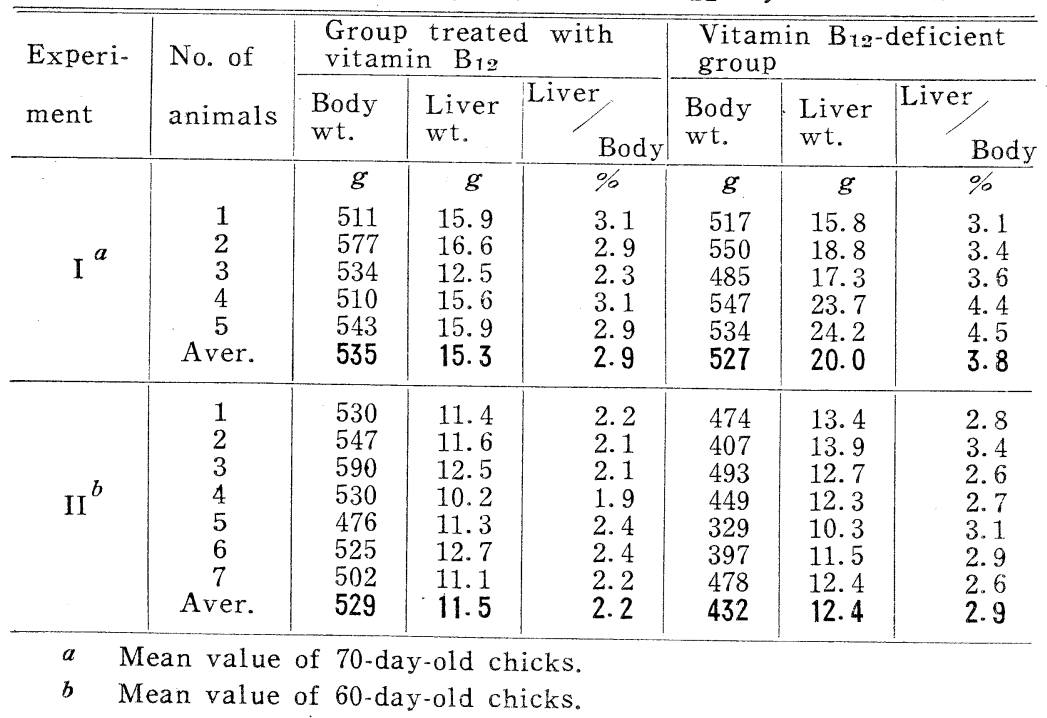


Table VII

The Change in Vitamin $B_{12}$ in the Liver and Blood of Vitamin B12-Deficient Chicks

\begin{tabular}{|c|c|c|c|c|}
\hline \multirow{2}{*}{$\begin{array}{l}\text { No. of } \\
\text { animals }\end{array}$} & \multicolumn{2}{|c|}{$\begin{array}{l}\text { Vitamin B } \mathrm{B}_{12} \text { content } \\
\text { in the group treated } \\
\text { with vitamin } \mathrm{B}_{12}\end{array}$} & \multicolumn{2}{|c|}{$\begin{array}{l}\text { Vitamin } \mathrm{B}_{12} \text { content } \\
\text { in the control group }\end{array}$} \\
\hline & Liver & Blood & Liver & Blood \\
\hline & $m \gamma / g$ & $m \gamma / m l$ & $m \gamma / g$ & $m \gamma / m l$ \\
\hline 1 & 21.51 & & 16.56 & \\
\hline 2 & 19.67 & $309^{a}$ & 10.30 & $205^{a}$ \\
\hline 3 & 30.19 & 3.09 & 12.07 & 2.05 \\
\hline 4 & 25.50 & & 17.45 & \\
\hline 5 & 18.00 & & 14.45 & \\
\hline 6 & 26.94 & $2.67^{\circ}$ & 12.52 & $2.16^{\circ}$ \\
\hline 7 & 24.22 & & 14. 71 & \\
\hline Aver. & 23.72 & 2.88 & 14.01 & 2.11 \\
\hline
\end{tabular}

a The collected blood of 4 chicks (Nos. 1-4) was investigated.

$b$ The collected blood of 3 chicks (Nos. 5-7) was investigated.

Table VIII

The Change in Thiamine in the Liver and Blood of Vitamin B12-Deficient Chicks

\begin{tabular}{|c|c|c|c|c|c|c|c|}
\hline \multirow{2}{*}{ Organ } & \multirow{2}{*}{$\begin{array}{l}\text { No. of } \\
\text { animals }\end{array}$} & \multicolumn{3}{|c|}{$\begin{array}{l}\text { The form of thiamine in the } \\
\text { group treated with vitamin } B_{12}\end{array}$} & \multicolumn{3}{|c|}{$\begin{array}{l}\text { The form of thiamine in } \\
\text { the control group }\end{array}$} \\
\hline & & Total & Free & Conj. & Total & Free & Conj. \\
\hline & & $\gamma / 100 \mathrm{~g}$ & $\gamma / 100 \mathrm{~g}$ & $\%$ & $\gamma / 100 \mathrm{~g}$ & $\gamma / 100 \mathrm{~g}$ & $\%$ \\
\hline Liver & $\begin{array}{c}1 \\
2 \\
3 \\
4 \\
5 \\
6 \\
7 \\
\text { Aver. }\end{array}$ & $\begin{array}{l}645 \\
590 \\
548 \\
675 \\
544 \\
606 \\
531 \\
592\end{array}$ & $\begin{array}{r}109 \\
103 \\
87 \\
113 \\
75 \\
82 \\
73 \\
92\end{array}$ & $\begin{array}{l}83.1 \\
82.5 \\
84.1 \\
83.3 \\
86.2 \\
86.5 \\
86.3 \\
84.5\end{array}$ & $\begin{array}{l}440 \\
510 \\
516 \\
532 \\
552 \\
486 \\
505 \\
506\end{array}$ & $\begin{array}{r}75 \\
89 \\
88 \\
120 \\
118 \\
93 \\
112 \\
99\end{array}$ & $\begin{array}{l}83.0 \\
82.5 \\
82.9 \\
77.4 \\
78.6 \\
80.9 \\
77.8 \\
80.4\end{array}$ \\
\hline & & $\gamma / m l$ & $\gamma / m l$ & $\%$ & $\gamma / m l$ & $\gamma / m l$ & $\%$ \\
\hline Blood & $\begin{array}{c}1 \\
2 \\
\text { Aver. }\end{array}$ & $\begin{array}{l}2.7 \\
2.8 \\
2.8\end{array}$ & $\begin{array}{l}1.7 \\
2.1 \\
1.9\end{array}$ & $\begin{array}{l}37.0 \\
25.0 \\
32.1\end{array}$ & $\begin{array}{l}2.5 \\
2.1 \\
2.3\end{array}$ & $\begin{array}{l}2.2 \\
1.7 \\
2.0\end{array}$ & $\begin{array}{l}12.0 \\
19.0 \\
13.0\end{array}$ \\
\hline
\end{tabular}


Table IX

The Change in Pantothenic Acid in the Liver and Blood of Vitamin B12-Deficient Chicks

\begin{tabular}{|c|c|c|c|c|c|c|c|}
\hline \multirow{2}{*}{ Organ } & \multirow{2}{*}{$\begin{array}{l}\text { No. of } \\
\text { animals }\end{array}$} & \multicolumn{3}{|c|}{$\begin{array}{l}\text { The form of pantothenic acid } \\
\text { in the group treated with } \\
\text { vitamin } B_{12}\end{array}$} & \multicolumn{3}{|c|}{$\begin{array}{l}\text { The form of pantothenic } \\
\text { acid in the control group }\end{array}$} \\
\hline & & Total & Free & Conj. Total & Total & Free & $\frac{\text { Conj. }}{\text { Total }}$ \\
\hline \multirow[b]{2}{*}{ Liver } & & $\gamma / g$ & $\gamma / g$ & $\%$ & $\gamma / g$ & $\gamma / g$ & $\%$ \\
\hline & $\begin{array}{c}1 \\
2 \\
3 \\
4 \\
5 \\
6 \\
7 \\
\text { Aver. }\end{array}$ & $\begin{array}{l}46.9 \\
67.4 \\
39.2 \\
45.0 \\
32.5 \\
56.1 \\
48.3 \\
47.9\end{array}$ & $\begin{array}{l}3.6 \\
7.1 \\
4.0 \\
5.0 \\
3.5 \\
5.1 \\
4.4 \\
4.7\end{array}$ & $\begin{array}{l}92.3 \\
89.5 \\
89.8 \\
88.9 \\
89.2 \\
90.9 \\
90.9 \\
90.2\end{array}$ & $\begin{array}{l}49.4 \\
31.5 \\
40.5 \\
30.0 \\
56.6 \\
35.4 \\
37.3 \\
40.1\end{array}$ & $\begin{array}{l}5.3 \\
4.6 \\
9.1 \\
3.5 \\
8.6 \\
4.2 \\
5.0 \\
5.8\end{array}$ & $\begin{array}{l}89.3 \\
85.4 \\
77.5 \\
88.3 \\
84.8 \\
88.1 \\
86.6 \\
85.5\end{array}$ \\
\hline \multirow[b]{2}{*}{ Blood } & & $r / m l$ & $\gamma / m l$ & $\%$ & $\gamma / m l$ & $\gamma / m l$ & $\%$ \\
\hline & $\begin{array}{c}1 \\
2 \\
\text { Aver. }\end{array}$ & $\begin{array}{l}0.94 \\
0.94 \\
0.94\end{array}$ & $\begin{array}{l}0.71 \\
0.73 \\
0.72\end{array}$ & $\begin{array}{l}25.0 \\
22.0 \\
23.0\end{array}$ & $\begin{array}{l}0.94 \\
0.94 \\
0.94\end{array}$ & $\begin{array}{l}0.71 \\
0.73 \\
0.72\end{array}$ & $\begin{array}{l}25.0 \\
22.0 \\
23.0\end{array}$ \\
\hline
\end{tabular}

Table $X$

The Change in Nicotinic Acid in the Liver and Blood of Vitamin B12-Deficient Chicks

\begin{tabular}{|c|c|c|c|c|c|c|c|}
\hline \multirow{2}{*}{ Organ } & \multirow{2}{*}{$\begin{array}{l}{ }^{\circ} \\
\text { No. of } \\
\text { animals }\end{array}$} & \multicolumn{3}{|c|}{$\begin{array}{l}\text { The form of nicotinic acid in } \\
\text { the group treated with } \\
\text { vitamin } \mathrm{E}\end{array}$} & \multicolumn{3}{|c|}{$\begin{array}{l}\text { The form of nicotinic } \\
\text { acid in the control group }\end{array}$} \\
\hline & & Total & Conj. & Conj. Total & Total & Conj. & $\frac{\text { Conj. }}{\text { Total }}$ \\
\hline & & $\gamma / g$ & $\gamma / g$ & $\%$ & $\gamma / g$ & $\gamma / g$ & $\%$ \\
\hline Liver & $\begin{array}{c}1 \\
2 \\
3 \\
4 \\
5 \\
6 \\
7 \\
\text { Aver. }\end{array}$ & $\begin{array}{l}25.2 \\
31.8 \\
17.4 \\
18.6 \\
20.3 \\
23.4 \\
26.4 \\
23.3\end{array}$ & $\begin{array}{l}22.8 \\
19.2 \\
14.7 \\
15.0 \\
14.4 \\
20.1 \\
20.1 \\
18.0\end{array}$ & $\begin{array}{l}90.5 \\
60.4 \\
84.5 \\
80.6 \\
70.9 \\
85.9 \\
76.1 \\
77.3\end{array}$ & $\begin{array}{l}27.9 \\
16.5 \\
26.7 \\
25.1 \\
30.0 \\
29.4 \\
31.8 \\
26.8\end{array}$ & $\begin{array}{r}9.3 \\
7.8 \\
11.2 \\
11.2 \\
13.2 \\
15.0 \\
11.4 \\
11.3\end{array}$ & $\begin{array}{l}33.3 \\
47.3 \\
41.9 \\
44.6 \\
44.0 \\
51.0 \\
35.8 \\
42.2\end{array}$ \\
\hline Blood & $\begin{array}{c}1 \\
2 \\
\text { Aver. }\end{array}$ & $\begin{array}{l}r / m l \\
1.20 \\
1.15 \\
1.18\end{array}$ & $\begin{array}{l}r / m l \\
1.11 \\
0.88 \\
1.00\end{array}$ & $\begin{array}{c}\% \\
92.5 \\
76.5 \\
84.7\end{array}$ & $\begin{array}{l}r / m l \\
1.10 \\
1.41 \\
1.26\end{array}$ & $\begin{array}{l}\gamma / m l \\
0.53 \\
0.71 \\
0.62\end{array}$ & $\begin{array}{c}\% \\
48.2 \\
50.4 \\
49.2\end{array}$ \\
\hline
\end{tabular}

\section{SUMMARY}

1. The change in vitamin $\mathrm{B}_{12}$ was studied in vitamin $\mathrm{B}_{12}$-deficient chicks, and the remarkable decrease of vitamin $\mathrm{B}_{12}$ was confirmed in the liver, while it was scarcely observed in the blood.

2. The in vivo formation of the conjugated forms of thiamine, pantothenic acid and nicotinic acid was repeatedly tested using vitamin $B_{12}$ 
deficient chicks. Vitamin $\mathrm{B}_{12}$-deficient chicks revealed a low content of conjugated vitamins in the liver, but no evidence was ever seen in the chicks treated with vitamin $B_{12}$. In the blood, a positive change was observed in nicotinic acid, pantothenic acid and thiamine.

3. From these findings, vitamin $B_{12}$ seems to be of special importance for the formation of coenzymes containing various vitamins.

Further enzymic investigation is now in progress.

\section{ACKNOWLEDGEMENT}

The expense of the research was partly defrayed from the grant in aid for Fundamental Scientific Research of Education Ministry and Vitamin B Research Committee.

\section{REFFERENCES}

1) Sahashi, Y., Iwamoto, K., and Hayashi, J., J. Biochem. 40, 245 (1953)

2) Sahashi, Y., Iwamoto, K., and Hayashi, J., J. Proc. APF Res. Comm. (Japan) 10, 4 (1954)

3) Sahashi, Y., Iwamoto, K., and Sakai, H., Proc. Japan Acad. 28, 578 (1952)

4) Sahashi, Y., and Iwamoto, K., ibid. 28, 573 (1952) 